\title{
Interpretation of the Geological Romance of Kendari Bay Using Landsat 5 TM
}

\author{
Andi Makkawaru ${ }^{1}$, Uca Sideng ${ }^{2}$, Sufrianto ${ }^{3}$ \\ ${ }^{1}$ BIRO ADMINISTRASI PEREKONOMIAN / DINAS PROVINSI SULAWESI TENGGARA \\ ${ }^{2}$ JURUSAN GEOGRAFI / FAKULTAS MATEMATIKA DAN ILMU PENGETAHUAN ALAM / \\ UNIVERSITAS NEGERI MAKASSAR \\ ${ }^{3}$ JURUSAN TEKNIK SIPIL / FAKULTAS TEKNIK / UNIVERSITAS SULAWESI TENGGARA
}

Email :

andimakkawaru@gmail.com ${ }^{1}$, ucasideng@unm.ac.id ${ }^{2}$, sufrianto@gmail.com ${ }^{3}$

(Received: Agu/2021; Reviewed: Sept/2021; Accepted: Sept/2021; Published: Okt/2021)

\begin{abstract}
Kendari Bay is part of Kendari City. Kendari Bay is a city landmark in addition to its economic and environmental functions.. The condition of Kendari Bay is experiencing a fairly high sedimentation problem, so that it begins to cause problems with land availability and space utilization patterns in the Kendari Bay area. The endogenous process of dynamic earth activities is a part that needs to be considered in managing that problems. This study aims the geological conditions of Kendari Bay by using remote sensing as a form of studying the geological conditions of Kendari Bay. Using Landsat 5 TM imagery in 1990, it was used to see the natural geological conditions of Kendari Bay, using the false color composite method and interpretation of photo images visually and validated through field observations. Landsat image processing and interpretation using Quantum GIS, resulted in Kendari bay can be divided into several physiography, namely coastal zone, estuary zone, fluvial zone, plain zone, hill zone, and mountain zone (Head land). The physiography can be seen from the geological characteristics such as the lithology which is composed of alluvial deposits to limestone. The results of interpretation of composite color images and validation of direct observation data in the field show a qualitative suitability.
\end{abstract}

Keywords: bay, geology, remote sensing, landsat

\section{ABSTRAK}

Teluk Kendari merupakan bagian dari Kota Kendari. Teluk Kendari merupakan landmark kota selain fungsi ekonomi dan lingkungannya. Kondisi Teluk Kendari mengalami permasalahan sedimentasi yang cukup tinggi, sehingga mulai menimbulkan permasalahan ketersediaan lahan dan pola pemanfaatan ruang di kawasan Teluk Kendari. Proses endogen dari aktivitas kebumian dinamis merupakan bagian yang perlu diperhatikan dalam mengelola permasalahan tersebut. Penelitian ini bertujuan untuk mengetahui kondisi geologi Teluk Kendari dengan menggunakan penginderaan jauh sebagai bentuk mempelajari kondisi 
geologi Teluk Kendari. Menggunakan citra Landsat 5 TM tahun 1990 digunakan untuk melihat kondisi geologi alam Teluk Kendari, menggunakan metode komposit warna semu dan interpretasi citra foto secara visual dan divalidasi melalui observasi lapangan. Pengolahan dan interpretasi citra landsat menggunakan Quantum GIS, menghasilkan Teluk Kendari dapat dibagi menjadi beberapa fisiografi, yaitu zona pesisir, zona estuari, zona fluvial, zona dataran, zona perbukitan, dan zona pegunungan (Head land). Fisiografi dapat dilihat dari karakteristik geologi seperti litologi yang tersusun dari endapan aluvial sampai batugamping. Hasil interpretasi citra komposit warna dan validasi data observasi langsung di lapangan menunjukkan kesesuaian kualitatif.

Kata Kunci: teluk; geologi; remote sensing; landsat.

\section{PENDAHULUAN}

Teluk Kendari adalah bagian dari Kota Kendari. Kota Kendari merupakan Ibukota Provinsi Sulawesi Tenggara, sehingga teluk Kendari menjadi landmark kota selain fungsi ekonomi dan lingkungan. Teluk merupakan salah satu bentuk geomorfologi pantai dimana teluk adalah bagian pantai yang menjorok ke daratan. Teluk memiliki peran penting disebabkan karena pada daerah teluk terdapat pantai yang merupakan batas pertemuan antara daratan dan lautan. Pada daerah teluk juga terdapat sumberdaya alam yang berlimpah dan bernilai ekonomi tinggi. Indonesia terletak di wilayah benua maritim dengan kepekaan terhadap curah hujan, radiasi bersih, fluks panas laten dan sensibel, dan evapotranspirasi di atas permukaan tanah (Tompubolon et al., 2020). Alasan tersebut membuat daerah teluk adalah wilayah yang sangat dinamis terhadap perubahan baik itu akibat alami maupun antropogenic.

Kondisi teluk Kendari mengalami masalah sedimentasi yang cukup tinggi (Putra et al.(2017); Subhan \& Afu (2017)). Geomorfologi Teluk Kendari memiliki karaktristik seperti geomorfologi Teluk Bima di Nusa Tenggara Timur, yang berbentuk semi tertutup yaitu mulut teluk yang menyempit dan badan air teluk yang besar di bagian dalam (Ghalib, 2021). Kota Kendari sendiri telah mengalami perkembangan yang cepat dari hanya kota pelabuhan biasa sejak awal abad ke-20 hingga tahun 1964, kemudian menjadi kota perdagangan, pendidikan dan jasa.

Penelitian (Jaya \& Rizal, 2021) menunjukkan bahwa perkembangan suatu wilayah akan seiring diikuti oleh perkembangan dalam pemanfaatan untuk lahan terbangun di wilayah tersebut. Seiring perkembangannya fungsi kota maka laju pertumbuhan penduduk dan aktivitas ekonomi di Kota Kendari ikut mengalami kemajuan yang sangat pesat utamanya kurun waktu 2000-an, sehingga mulai menimbulkan masalah ketersediaan lahan dan pola pemanfaatan ruang khususnya di daerah teluk Kendari. Deb et al.(2020) dan Tian et al.(2016), mempelajari perubahan bentuk geomorfologi daerah pantai tertutup yang sangat dinamis akibat aktivitas manusia dan sungai yang mengalir ke dalam sistim periran tertutup (teluk) tersebut.

Perubahan bentuk bentang alam teluk Kendari dan masalah sedimentasi yang terjadi, selain akibat aktivitas manusia maupun kondisi iklimnya, yang dikenal dengan istilah proses eksogen dalam pembentukan bentang alam. Maka proses endogen juga turut berperan penting. Proses pembentukan geologi daerah teluk Kendari sebagai proses endogen yang tidak kalah penting. Proses endogen dari aktivitas dinamis bumi merupakan bagian yang perlu diperhatikan 
dalam mengelola permasalahn sedimentasi maupun perubahan bentang alam teluk Kendari. Untuk memahami proses endogen di daerah teluk Kendari, maka perlu diketahui karakteristik geologi teluk Kendari, melalui pengenalan kondisi geologi yang ada sekarang ini. Kondisi geologi berupa litologi, struktur geologi dan geomorpologi sendiri menjadi sulit di pelajari dengan situasi kepadatan penduduk kota yang telah tersusun oleh bangunan-bangunan struktur buatan. Pendekatan menggunakan remote sensing untuk melihat kondisi geologi teluk Kendari dalam tahun-tahun lampau dapat dipakai sebagai bentuk studi kondisi geologi teluk Kendari lebih baik.

Defenisi remote sensing adalah ilmu pengetahuan dan seni pemerolehan informasi tentang suatu objek, daerah, atau fenomena melalui analisis data yang diperoleh dengan suatu alat yang tidak bersentuhan dengan objek, daerah, atau fenomena di dalam penyelidikan tersebut (Ramadhan \& Putri, 2020). Adapun teknik remote sensing telah banyak digunakan didalam melakukan pemetaan geologi baik berupa colour composite, PCA maupun algorithma tertentu. Jassin, (2020), Mohammadpour et al.(2020), Ramadhan \& Putri, (2020), Ghaniansah et al., 2016, Yasin et al (2016), Sulaksana et al. (2013) menggunakan remote sensing dalam pemetaan geologi untuk mengenali aspek geologi permukaan, mendeliniasi litologi, kenampakan struktur geologi, variasi tanah (soil) dan eksplorasi mineral. Gandhi M.S and Mohan V.R, 2013, menggunakan remote sensing untuk memetakan pola liniament struktur geologi dan perkembangan tektonik.

Secara regional, teluk Kendari berada pada tatanan geologi daerah Sulawesi Tenggara. Geologi daerah Sulawesi tenggara tersusun oleh batuan alas metamorf berderajat rendah yang diperkirakan berumur paleozoikum dan berasal dari mikro kontinen ( benua renik) lempeng australia. Selanjutnya diatas dari batuan alas terbentuk batuan sedimen klastik dan batuan karbonat yang berumur mesozoikum. Sedimen Mesozoikum ini ditindih tak selaras oleh batuan karbonat laut dangkal dari Formasi Tampakura. Batuan asal samudra yang yang bergerak ke tenggara bertabrakan dengan kepingan benua di Sulawesi Tenggara dan selanjutnya diendapkan batuan sedimen berumur tersier-kuarter (Surono, 2002 dalam Jassin, 2020) lihat gambar 1. Berdasarkan peta regional tersebut, Nampak bahwa teluk Kendari didominasi oleh batuan sedimen yang berumur tersier-kuarter.

Pemanfaatan remote sensing menjadi salah satu alternative metode didalam melakukan perencanaan, monitoring dan evaluasi kondisi teluk Kendari dengan kriteria data yang cepat, akurat dan mudah di akses tersebut. Menurut (Miswar et al., 2020) bahwa sistem informasi geografis merupakan salahsatu kajian ilmu geografi yang beragam dalam hal penerapan dalam kehidupan sehari-hari, Penelitian ini bertujuan untuk menemukan serta mengenali karakteristik geomorfologi dan geologi di sekitar pantai Teluk Kendari dengan menggunaan teknik remote sensing. Hasil penelitian ini dapat dipakai sebagai data pendukung dalam rangka penyusunan sistem manajemen pengelolaan Teluk Kendari yang lebih terpadu dan menyeluruh. Pendekatan penelitian didasarkan kepada mengenali kondisi geomorfologi dan geologi Teluk Kendari secara kualitatif dengan titik beratnya mengenal roman geologi sebagai penyusun yang mempengaruhi geomorfologi teluk Kendari melalui interpretasi citra satelit. Harapannya dapat dipakai sebagai data dasar bagi pemerintah Kota Kendari selaku pihak yang berperan didalam kebijakan menata wilayah Teluk Kendari dalam pola ruang dan struktur ruang termasuk memonitor dan mengawasi perubahan bentang alam dari teluk Kendari. Monitoring dan evaluasi perubahan dinamis teluk Kendari membutuhkan suatu metode yang cepat, akurat dan mudah dalam akses data untuk menganalisis dan memonitor perubahan kondisi ruang Teluk Kendari. 


\begin{abstract}
METODE
Jenis penelitian yang digunakan pada penelitian ini adalaha penelitian kuantitatif dengan pendekatan interpretasi citra penginderaan jauh untuk memperoleh informasi tentang fisiografi dan geologi yang Menyusun geomorfologi teluk Kendari. Hidayat, (2021); Omar (2021), Nataliaet al. (2021) dan Yusuf, (2020) menggunakan metode ini untuk memonitoring dan mengevaluasi perubahan bentang alam pantai. Alat dan bahan yang digunakan dalam penelitian ini, yaitu citra landsat wilayah Teluk Kendari yang merupakan hasil cliping citra Landsat 5 TM path 112 raw 63 tahun 1990 yang diperoleh dari mendownload melalui situs resmi USGS dengan EarthExplorer, software pengolahan citra dengan Quantum GIS (QGIS), GPS Navigasi, Kompas geologi, Palu Geologi dan peralatan lapangan lainnya untuk keperluan validasi data hasil analisis citra Landsat. Data citra landsat memiliki multi-saluran dengan kemampuan komposit antar saluran yang mampu menonjolkan karakteristik suatu wilayah (Elfatma, 2020). Citra Landsat 5 TM tahun 1990 dipilih sebagai citra untuk dipakai dalam analisis geologi dan geomorfologi teluk Kendari didasari oleh pada tahun tersebut, struktur antropogenik masih terbatas sehingga lebih memberikan keakuratan untuk mengidentifikasi geologi dan geomorfologi yang lebih baik.

Lokasi penelitian di fokuskan di sekitar Teluk Kendari, dimana Teluk Kendari sendiri berlokasi sebelah timur dari lengan tenggara pulau Sulawesi, dengan posisi geografi memanjang dari Utara ke Selatan $03^{\circ}-54^{\circ} 30^{\circ}-4^{\circ} 3^{\circ} 11^{\circ}$ lintang selatan dan membentang dari Barat ke Timur antara $122^{\circ} 23^{\circ}-122^{\circ} 39^{\circ}$ Bujur Timur (gambar 2). Pengambilan lokasi validasi data bisa dengan cara random sampling maupun dengan cara sitematik random sampling di beberapa tempat terpilih. Penelitian kali ini menggunakan metode random untuk menentukan lokasi pengamatan langsung dilapangan dan hasilnya menunjukkan bahwa hasil interpretasi fitur geologi dari citra warna komposit dan hasil validasi data dilapangan, cukup baik (gambar 5). Untuk itu validasi data struktur lineament hasil analisis digital dapat digabungkan dengan data geofisika seperti data geofisika seperti (Mohammadpour et al., 2020) atau dengan data digital elevation model dari ASTER ataupun SRTM (Jassin,(2020); Sukiyah et al., (2018, 2020); Yasin et al., (2016)) sehingga dapat dieliminir lineament citra yang bukan merupakan hasil struktur geologi. Pada penelitian awal langkah tersebut tidak dilakukan dan hanya analisis berdasarkan pengamatan berbagai warna komposit saja.

Metode analisis remote sensing yang digunakan dalam penelitian adalah metode interpretasi melalui metode colour composite band (saluran warna komposit). Metode warna komposit adalah mengganti panjang gelombang di saluran merah (red), hijau (green), biru (blue) yang biasa disebut gelombang tampak (visible) dengan panjang gelombang yang merupakan kombinasi dari band 1,2,3 (visible),4 (NIR) ,5 dan 7 (SWIR) dalam saluran $R G B$ sehingga menghasilkan warna citra yang mudah dikenali oleh mata interpreter. Adapun diagram alur penelitiannya dapat dilihat pada gambar 3. Bajwa et al.(2020), Larocque et al. (2020), dan Farda, (2017) menggunakan teknik warna komposit dalam interpretasi citra dan menganalisis dengan konsep dasar pengenalan citra seperti pada geologi foto, yaitu berdasarkan rona, tekstur, pola, bentuk, ukuran, letak (site), asosiasi dan bayangan.

Interpretasi citra yang akan diidentifikasi variable-variabel geologi seperti pola sebaran litologi, struktur geologi berupa pola struktur garis (lineament), serta bentang alam (fisiografi) yang dapat dikenal seperti sungai, lereng, perbukitan, pegunugan dan pantai. Larocque et al.(2020), Farda (2017), Ferral et al. (2019), Kumar \& Mutanga, (2018), Sidhu et al., (2018);
\end{abstract}


email: lageografia@unm.ac.id

Jurusan Geografi Fakultas Matematika dan Ilmu Pengetahuan Alam

Universitas Negeri Makassar Sulawesi Selatan, Indonesia

Andi Makkawaru, Uca Sideng, Sufrianto, 2021, Interpretasi Roman Geologi Teluk Kendari Menggunakan Landsat 5 TM

Tian et al., (2016) menggunakan landsat 5 TM mengidentifikasi kenampakan-kenampakan bentang alam melalui metode colour composite dengan susunan band true colour composite dan false colour composite untuk mengenali fisiografi sungai (sistim fluvial) dan garis pantai (coastal line).

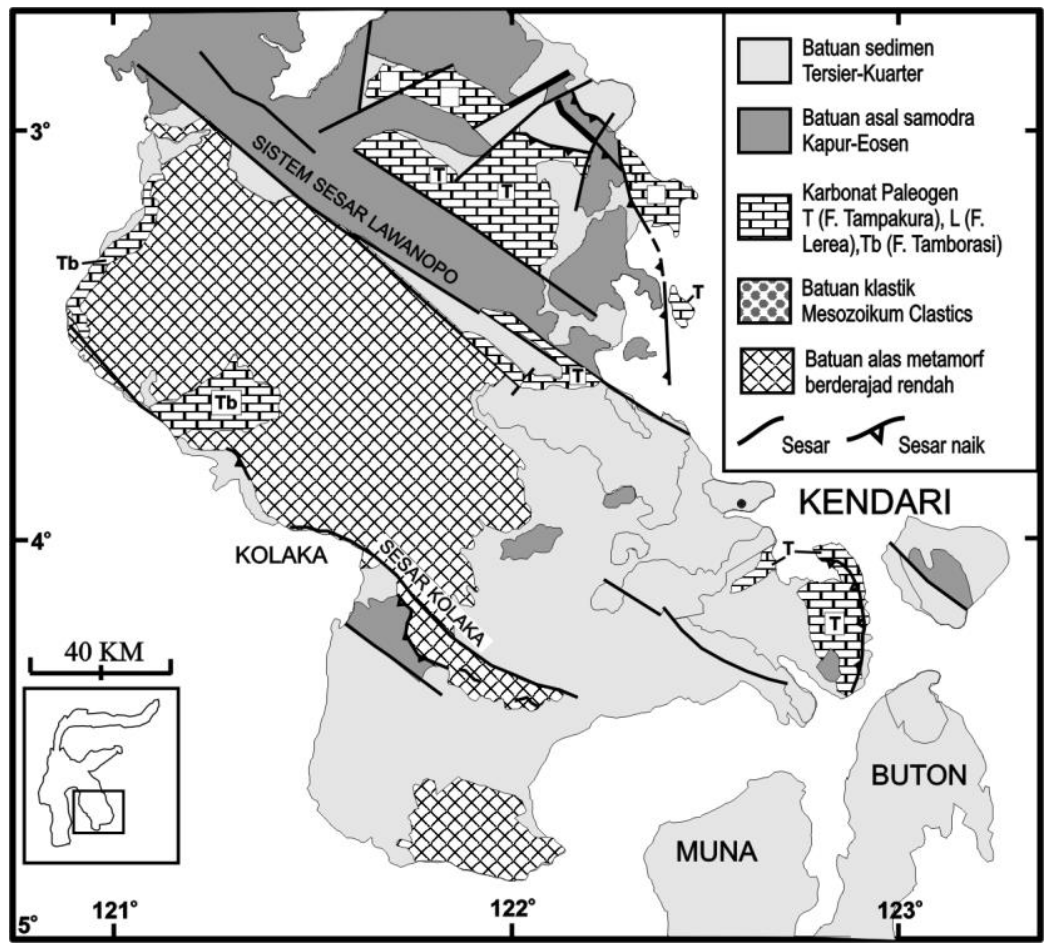

Gambar 1. Geologi Regional Sulawesi Tenggara yang disederhanakan. Sumber : Jassin 2020.

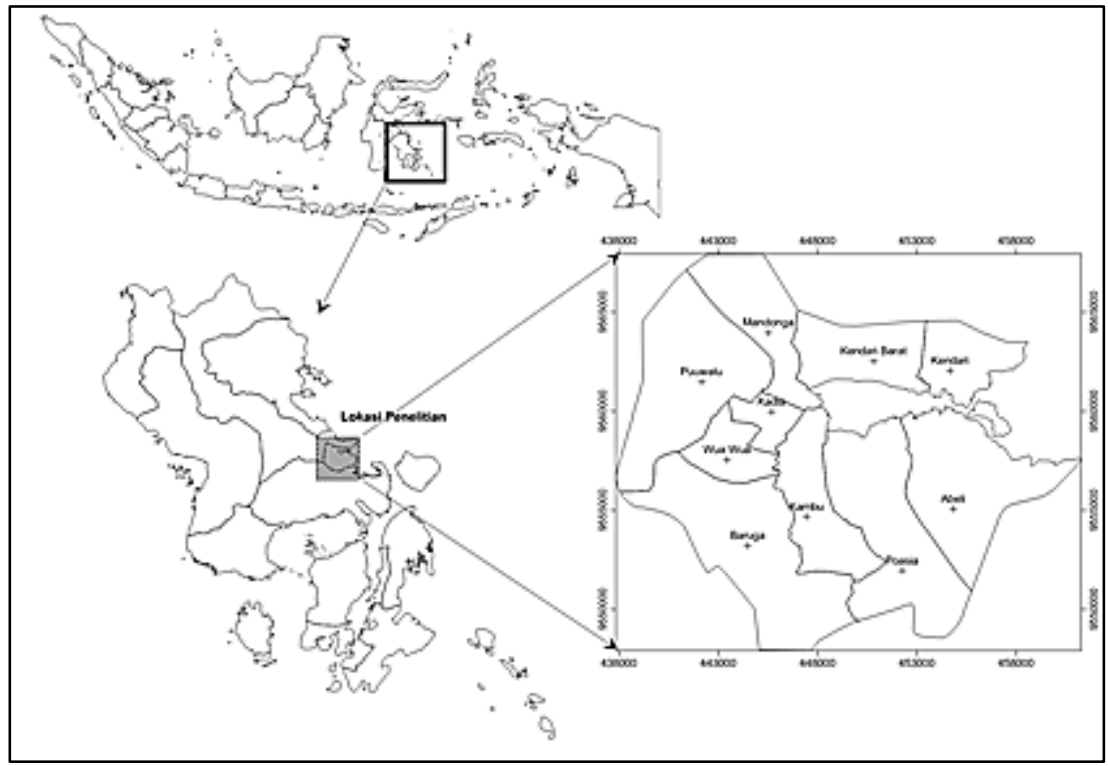


Gambar 2. Lokasi daerah penelitian.

\section{HASIL DAN PEMBAHASAN}

\section{Hasil}

Hasil temuan dari penelitian ini menunjukkan bahwa Citra landsat 5 TM path112 raw63 tahun 1990 yang telah dilakukan koreksi geometrik dan radiometric jauh lebih baik dibandingkan citra tanpa koreksi. Koreksi ini bertujuan agar citra memiliki georeferensi, yaitu memiliki koordinat bumi yang sesuai. Koreksi geometrik citra menggunakan QGIS dengan metode titik kontrol (Ground Control Point) citra ke citra. Dipilihnya metode koreksi geometrik citra ke citra karena metode ini mampu mengoreksi kesalahan yang diakibatkan oleh pergeseran relief pada citra, tidak seperti metode koreksi geometrik citra ke peta, namun untuk mengukur luasan, dan jarak maka koreksi ini tidak sebaik koreksi citra ke peta. Setelah citra telah terkoreksi geometrik maka selanjutnya dilakukan koreksi radiometrik, hasil perbandingan nilai pixel sebelum dikoreksi dan setelah koreksi radiometrik dapat dilihat pada tabel 1 .

Interpretasi warna komposit dari citra landsat $5 \mathrm{TM}$, dapat membedakan dengan jelas antara daratan (land) dengan laut (sea), sehingga pertemuan antara daratan dan lautan berupa pantai nampak jelas. Abboud \& Nofal, (2020) dan Ramadhan \& Putri (2020), mengidentifikasi geomorfologi pantai berdasarkan ukuran butir sedimen pantai, bentuk medan, aliran sungai dan gelombang laut menjadi tiga, yaitu : Pantai batu, Pantai pasir, pantai Lumpur.Pada citra warna composit band 453 menunjukkan fisiografi pantai dapat dibedakan dengan baik sesuai kriteria tersebut. Pola lineament yang diamati pada citra dengan warna komposit adalah melalui pendekatan asosiasi morfologi kelurusan dari lembah dan pola pengaliran. Lineament teramati bisa saja nantinya bukan berasal dari kelurusan akibat struktur geologi seperti sesar ataupun fracture-fracture geologi lainnya tetapi bisa berupa gawir erosi dan penjajaran vegetasi yang rapat.

Pengamatan visual didapatkan bahwa fisiografi dan karakter geologi daerah Teluk Kendari dari proses pengenalan berdasarkan prinsip pengenalan geologi foto, memberikan gambaran roman geologi yang dapat dibedakan fiturnya dengan cukup baik (gambar 3). Perbedaan morfologi sangat jelas terlihat antara unit-unit morfologi satu dengan lainnya. Batas tubuh air dengan daratan terbedakan dengan warna yang baik pada warna komposit 457 sehingga bisa dilakukan penelitian lanjutan tentang garis pantai (shoreline) di Teluk Kendari. Pada warna komposit 237 terlihat dengan jelas sedimentasi di daerah estuari. Untuk variasi litologi dan dugaan struktur geologi berupa lineament sangat jelas dan dapat pula di bedakan secara visual kualitatif pada warna komposit 457.

Tabel 1. Hasil Koreksi Radiometrik Citra Landsat 5 TM wilayah Teluk Kendari.

\begin{tabular}{|c|c|c|c|c|c|c|c|c|c|c|c|c|c|}
\hline \multirow{2}{*}{ Pixel } & \multirow{2}{*}{ Satuan } & \multicolumn{2}{|c|}{ Band 1} & \multicolumn{2}{|c|}{ Band 2} & \multicolumn{2}{|c|}{ Band 3} & \multicolumn{2}{|c|}{ Band 4} & \multicolumn{2}{|c|}{ Band 5} & \multicolumn{2}{|c|}{ Band 7} \\
\hline & & Min & Max & Min & Max & Min & Max & Min & Max & Min & Max & Min & Max \\
\hline DN & & 52 & 179 & 124 & 146 & 1 & 193 & 10 & 127 & 1 & 148 & 1 & 111 \\
\hline Reflectance & $\mathrm{W} / \mathrm{m}^{2} \mathrm{sr} \mu \mathrm{m}$ & 0.001253 & 0.007134 & 0.0004700 & .004322 & 0.000098 & 0.000710 & 0.000090 & 0.0004150 & .000088 & .000275 & 0.000164 & 0.000444 \\
\hline
\end{tabular}

Sumber: Hasil olah data, 2021 


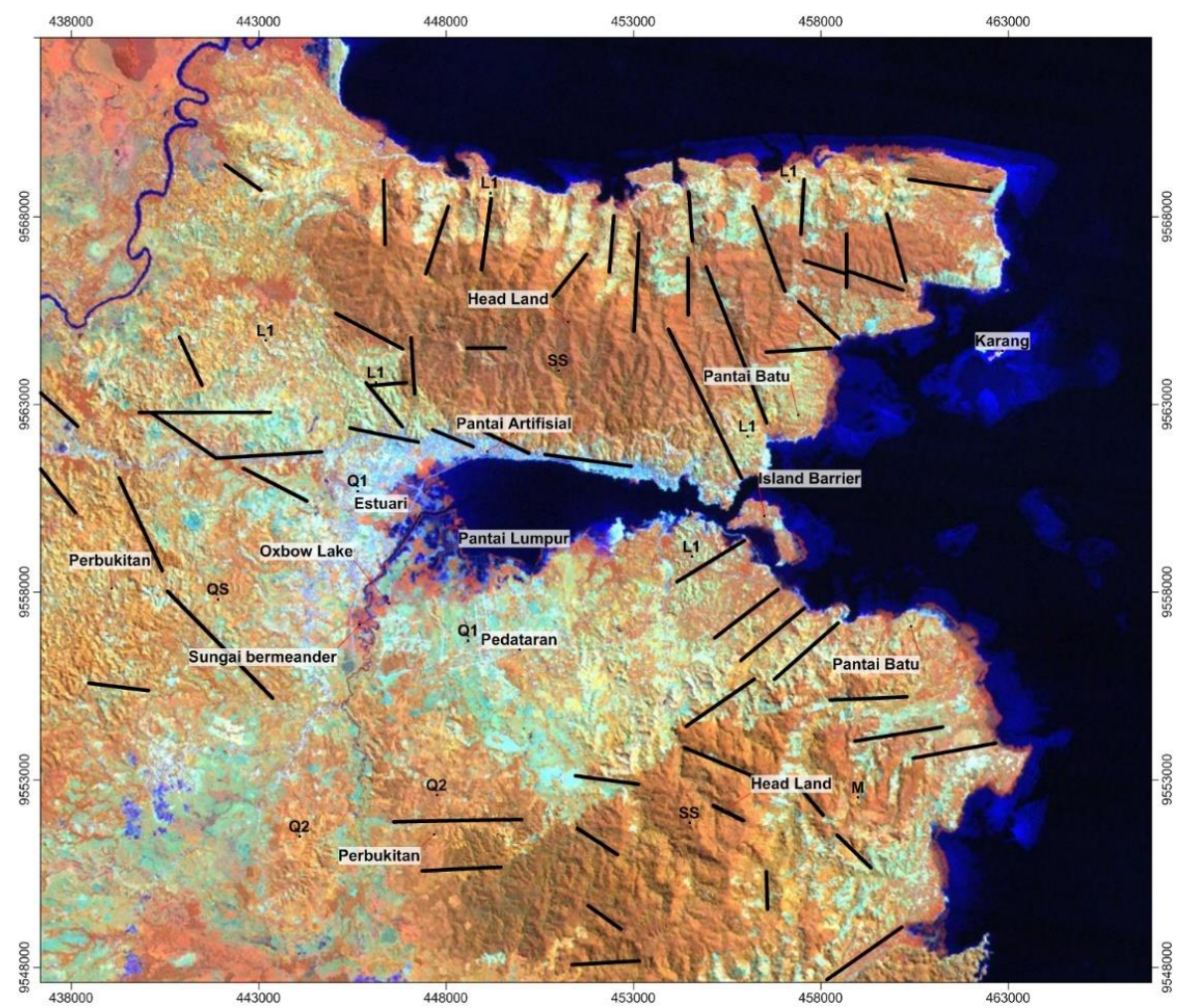

Gambar 3. Roman Geologi Teluk berdasarkan visual Interpretasi visual citra landsat 5 TM warna komposit band 453.

Tabel 2. Hasil pembagian geologi dan fisografi wilayah Teluk kendari berdasarkan pengenalan visual yang nampak pada citra warna komposit

\begin{tabular}{|c|c|c|c|c|}
\hline \multicolumn{2}{|c|}{$\begin{array}{l}\text { Roman Geologi / } \\
\text { Fisiografi }\end{array}$} & \multirow[t]{2}{*}{ Litologi } & \multirow[t]{2}{*}{ Struktur Geologi } & \multirow[t]{2}{*}{ Ciri Utama } \\
\hline Zona & Sub-zona & & & \\
\hline \multirow[t]{4}{*}{ Pantai } & Pantai Batu & $\begin{array}{l}\text { Batu } \\
\text { gamping (L) }\end{array}$ & $\begin{array}{l}\text { Lineament densitas } \\
\text { tinggi }\end{array}$ & $\begin{array}{l}\text { Tekstur kasar, warna } \\
\text { cokelat }\end{array}$ \\
\hline & $\begin{array}{l}\text { Pantai } \\
\text { Lumpur }\end{array}$ & Lumpur & Tidak nampak & $\begin{array}{l}\text { Tekstur halus, warna } \\
\text { biru muda }\end{array}$ \\
\hline & Karang & Coral & Tidak nampak & Dikelilingi tubuh air \\
\hline & $\begin{array}{l}\text { Pantai } \\
\text { Artifisial }\end{array}$ & Concreate & Tidak nampak & $\begin{array}{l}\text { Pola lurus, tekstur } \\
\text { halus, warna biru } \\
\text { muda cerah. }\end{array}$ \\
\hline Island Barier & & $\begin{array}{l}\text { Batu } \\
\text { gamping (L) }\end{array}$ & Tidak nampak & Pulau di depan pantai \\
\hline Estuari & Marsh & $\begin{array}{l}\text { Lumpur, } \\
\text { Aluvium } \\
\text { (Q1) }\end{array}$ & Tidak nampak & $\begin{array}{l}\text { Pola pengaliran, ujung } \\
\text { segiempat, tone gelap, } \\
\text { warna iru tua }\end{array}$ \\
\hline Fluvial & Sungai & Aluvium & Tidak nampak & Pola berkelok-kelok \\
\hline
\end{tabular}


p-ISSN: 1412-8187 e-ISSN: 2655-1284

email: lageografia@unm.ac.id

Jurusan Geografi Fakultas Matematika dan Ilmu Pengetahuan Alam

Universitas Negeri Makassar Sulawesi Selatan, Indonesia

Andi Makkawaru, Uca Sideng, Sufrianto, 2021, Interpretasi Roman Geologi Teluk Kendari Menggunakan Landsat 5 TM

\begin{tabular}{|c|c|c|c|c|c|}
\hline & $\begin{array}{l}\text { meander } \\
\text { Oxbow } \\
\text { lake }\end{array}$ & $\begin{array}{l}\text { (Q1) } \\
\text { Aluvium } \\
\text { (Q1) }\end{array}$ & & Tidak nampak & Pola bentuk U \\
\hline Pedataran & & $\begin{array}{l}\text { Aluvium } \\
\text { (Q1) }\end{array}$ & & $\begin{array}{l}\text { Lineament densitas } \\
\text { rendah }\end{array}$ & $\begin{array}{l}\text { Tekstur halus, warna } \\
\text { biru ke hijau muda }\end{array}$ \\
\hline Perbukitan & & $\begin{array}{l}\text { Aluvium } \\
\text { Koluvial } \\
\text { (Q2) }\end{array}$ & - & $\begin{array}{l}\text { Lineament densitas } \\
\text { rendah }\end{array}$ & $\begin{array}{l}\text { Tekstur halus, warna } \\
\text { cokelat }\end{array}$ \\
\hline Pegunungan & $\begin{array}{l}\text { Head Land } \\
\text { (U) } \\
\text { Head Land } \\
\text { (S) }\end{array}$ & $\begin{array}{l}\text { Batupasir } \\
\text { (SS) } \\
\text { Batupasir } \\
\text { (SS), } \\
\text { Metamorf } \\
\text { (M) }\end{array}$ & & $\begin{array}{l}\text { Lineament densitas } \\
\text { tinggi } \\
\text { Lineament densitas } \\
\text { rendah }\end{array}$ & $\begin{array}{l}\text { Tekstur halus, warna } \\
\text { cokelat tua } \\
\text { Tekstur haus-kasar, } \\
\text { warna cokelat menuju } \\
\text { hijau }\end{array}$ \\
\hline
\end{tabular}
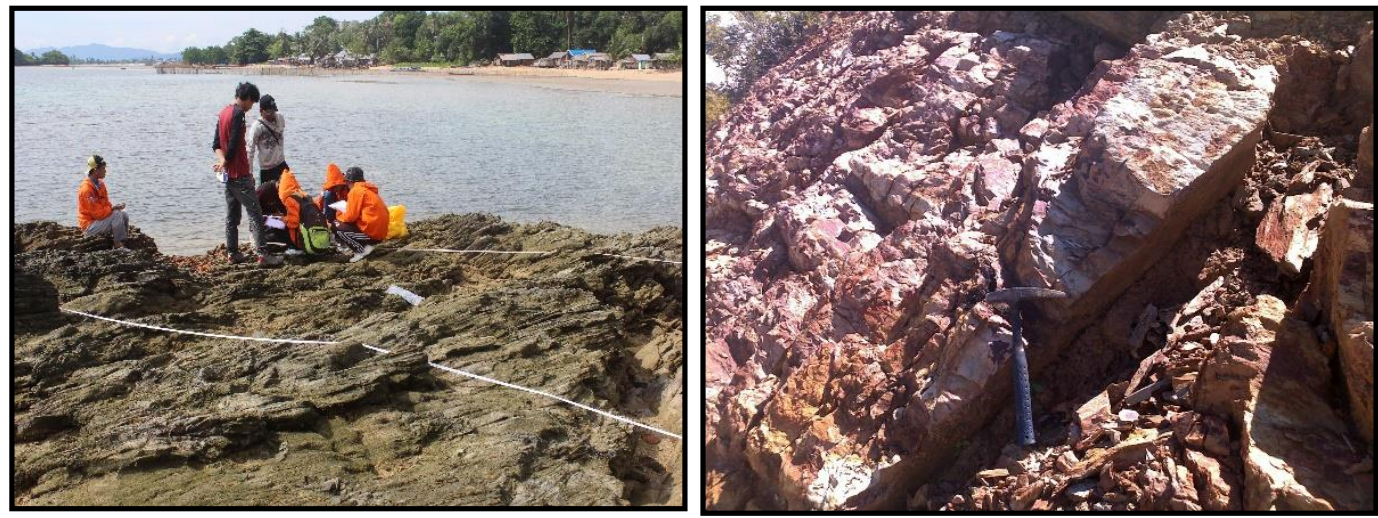

Gambar 4. Kegiatan lapangan untuk validasi hasil analisis visual kuantitatif citra landsat 5 TM dengan metode warna komposit.(A). Kenampakan Pantai Berbatu dan (B). Lapisan miring pada batupasir.

\section{Pembahasan}

Gabungan band yang membentuk false colour dengan analisis sederhana melalui pengamatan visual citra warna komposit, pada daerah Penelitian sudah dapat di bagi kedalam beberapa zona yang dapat distudi lebih lanjut (Tabel 2). Citra memberikan potensi informasi berharga dalam proses membuat suatu keputusan. Potensi informasi geologi yang berguna seperti geomorfologi, hidrologi, tanah (soil), ragam batuan dan lineament dapat diolah dengan lebih kompleks melalui cara matematis (algorithma) dengan bantuan software pengolah citra Quantum GIS (QGIS) yang open source dan lainnya, untuk hasil terutama deliniasi antar unit geologi yang lebih memberikan spesifik informasi seperti water modelling, endapan kuarter, dan modeling tektonik.

Berdasarkan hasil interpretasi citra warna komposit maka tahap akhir adalah validasi data. Hasil penelitian menunjukkan bahwa pemanfaatan citra landsat 5 TM yang digunakan 
sebagai metode dalam mengenali (identifikasi) fitur geologi, monitoring dan evaluasi dinamika geologi teluk Kendari sangat baik. Resolusi 30 m landsat 5 TM masih mampu mengidentifikasi fitur geologi walaupun belum dapat dengan tegas menarik batas antar satuan batuan jika dengan visualisasi pengenalan objek dalam citra. Perlu menggunakan atau mengkombinasikan dengan teknik lainnya seperti Principal Component Analysis (PCA) atau dengan algorithma seperti NDWI, NDVI dan semacamnya, selanjutnya memvalidasinya dengan data geofisika dan obeservasi dilapangan langsung, sehingga datanya menjadi lebih baik lagi. Hal tersebut sejalan dengan salah satu pilar dalam Kebijakan Satu Peta (One Map Policy) yaitu adanya satu standar, khususnya standar kualitas yang digunakan sebagai rekaman fenomena tentang lokasi geografis, dimensi/ukuran, dan karakteristik objek yang berada di seluruh bagian yang ada di permukaan bumi, data geospasial harus dapat mewakili keadaan sebenarnya di lapangan (Lusy et al., 2020). Menurut (Hadibasyir et al., 2020) bahwa salah satu kegunaan dari normalized difference vegetation index (NDVI) yaitu untuk memperoleh data mengenai kondisi permukaan bumi seperti pemetaan tutupan vegetasi dengan menggunakan

\section{SIMPULAN DAN SARAN}

\section{Simpulan}

Berdasarkan hasil penelitian pengamatan visual citra warna komposit dari citra landsat 5 TM, didapatkan kesimpulan bahwa karakteristik fitur geologi Teluk Kendari dapat dengan baik dikenali melalui analisis visual citra warna komposit. Teluk Kendari sudah dapat di bagi kedalam beberapa zona yang dapat distudi lebih lanjut, yaitu zona pantai, zona estuari, zona pedataran, zona perbukitan, dan zona pegunungan (Head land). Kekurangan dari citra warna komposit adalah belum dapat mendeliniasi dengan baik batas morfologi dan litologi daerah Teluk Kendari. Hasil interpretasi citra warna komposit dan validasi data pengamatan langsung dilapangan menunjukkan kesesuaian secara kualitatif.

\section{Saran}

Penelitian ini diharapkan menjadi pedoman dan dipakai sebagai data pendukung dalam rangka penyusunan sistem manajemen pengelolaan Teluk Kendari yang lebih terpadu dan menyeluruh. Diharapkan pula kepada para peneliti untuk senantiasa meneruskan penelitian yang relevan guna mendapatkan data yang terbaru sehingga dapat diimplementasikan dikehidupan masyarakat.

\section{DAFTAR RUJUKAN}

Abboud, I. A., \& Nofal, R. A. E. (2020). Using Remote Sensing Techniques To Interpret Geomorphological Features Along The East Coast Of The Red Sea, At Yanbu, Saudi Arabia. Arabian Journal Of Geosciences 2020 13:14, 13(14), 1-19. Https://Doi.Org/10.1007/S12517-020-05635-W.

Bajwa, R. S., Ahsan, N., \& Ahmad, S. R. (2020). A Review Of Landsat False Color Composite Images For Lithological Mapping Of Pre-Cambrian To Recent Rocks: A Case Study Of Pail/Padhrar Area In Punjab Province, Pakistan. Journal Of The Indian Society Of Remote 
Sensing 2020 48:5, 48(5), 721-728. Https://Doi.Org/10.1007/S12524-019-01090-7

Deb, S., Guyondet, T., Coffin, M., Barrell, J., Comeau, L., Deb, S., Guyondet, T., Coffin, M., Barrell, J., \& Comeau, L. (2020). Modeling The Effect Of Inlet Geomorphic Changes On The Circulation Dynamics In A Semi-Enclosed Coastal Estuary. AGUFM, 2020, OS0090009. Https://Ui.Adsabs.Harvard.Edu/Abs/2020AGUFMOS0090009D/Abstract

Elfatma, O. (2020). Fitur Pengganti Untuk Interpretasi Garis Pantai Bentuk Lahan Karst dan Fluvio-Marin. LaGeografia, 18(3), 245-254.

Farda, N. M. (2017). Multi-Temporal Land Use Mapping Of Coastal Wetlands Area Using Machine Learning In Google Earth Engine. IOP Conference Series: Earth And Environmental Science, 98(1). Https://Doi.Org/10.1088/1755-1315/98/1/012042

Ferral, A., Luccini, E., Aleksinkó, A., \& Scavuzzo, C. M. (2019). Flooded-Area Satellite Monitoring Within A Ramsar Wetland Nature Reserve In Argentina. Remote Sensing Applications: $\quad$ Society And Environment, $15, \quad 100230$. Https://Doi.Org/10.1016/J.Rsase.2019.04.003

Ghalib, N. M. (2021). Dinamika Total Suspended Solid (Tss) Dan Land Cover (Lc) Di Perairan Pelabuhan Bima, Teluk Bima.

Ghaniansah, A. F., Tawil, S., Muslim, D., \& Sukiyah, E. (2016). Karakterisik Morfotektonik DAS Buol Bagian Hulu Yang Tersusun Oleh Batuan Berumur Kuarter Dan Tersier Kabupaten Buol Provinsi Sulawesi Tengah. Bulletin Of Scientific Contribution.

Hadibasyir, H. Z., Fikriyah, V. N., Sunariya, M. I. T., \& Danardono, D. (2020). Pemetaan Kondisi Ekologi Perkotaan Skala Mikro Menggunakan Citra Landsat 8 di Kota Semarang. LaGeografia, 18(3), 209-220.

Jassin, A. M. I. (2020). Karakteristik Produk Tektonik-Erosi- Sedimentasi Cekungan Kendari Dan Implikasinya Terhadap Penataan Ruang Kota Kendari. Http://Repository.Unpad.Ac.Id/Frontdoor/Index/Index/Docid/39032

Jaya, R., \& Rijal, A. S. (2021). Analisis Keterlanjuran Ruang Lingkungan Universitas Muhammdiyah Gorontalo. LaGeografia, 19(2), 211-225.

Kumar, L., \& Mutanga, O. (2018). Geospatial Data Analysis On Google Earth Engine. In Journal Of The Remote Sensing Society Of Japan (Vol. 38, Issue 2). Https://Doi.Org/10.11440/Rssj.38.125

Larocque, A., Leblon, B., Woodward, R., \& Bourgeau-Chavez, L. (2020). Wetland Mapping In New Brunswick, Canada With Landsat5-Tm, Alos-Palsar, And Radarsat-2 Imagery. Https://Doi.Org/10.5194/Isprs-Annals-V-3-2020-301-2020

Lusy, I., Suwarni, N., Miswar, D., \& Jaya, M. T. B. (2020). Pemodelan Bencana Longsor Berbasis Spasial. LaGeografia, 19(1), 16-27.

Miswar, D., Sugiyanta, I. G., \& Yarmaidi, Y. (2020). Kajian Geografis Potensi Wilayah Berbasis Geospasial Kabupaten Pringsewu. LaGeografia, 18(3), 255-268.

Mohammadpour, M., Bahroudi, A., \& Abedi, M. (2020). Automatic Lineament Extraction Method In Mineral Exploration Using CANNY Algorithm And Hough Transform. Geotectonics 2020 54:3, 54(3), 366-382. Https://Doi.Org/10.1134/S0016852120030085

Omali, T. U. (2021). Utilization Of Remote Sensing And GIS In Geology And Mining. International Journal Of Scientific Research In Research Paper. Multidisciplinary Studies E, 7(4), 17-24. Https://Www.Researchgate.Net/Publication/353979577

Putra, A., Husrin, S., \& Mutmainah, H. (2017). Pola Sebaran Kualitas Air Berdasarkan Kesesuaian Baku Mutu Untuk Biota Laut Di Teluk Kendari Provinsi Sulawesi Tenggara. Maspari Journal: Marine Science Research, 9(1), 51-60. 
Ramadhan, D., \& Putri, S. (2020). Identification Of Geomorphology And Litology Based On Analysis Of Landsat-8 Satellite Images In Padang City. International Remote Sensing Applied Journal, 1(1), 7-11. Http://Irsaj.Ppj.Unp.Ac.Id/Index.Php/IRSAJ/Article/View/10

SERVICE, N. R. (USDA) C. (2012). Natural Resources Conservation Service. In Version 4.2 (Vol. 49, Issue 11). Https://Doi.Org/10.5860/CHOICE.49-6302

Sidhu, N., Pebesma, E., \& Câmara, G. (2018). Using Google Earth Engine To Detect Land Cover Change: Singapore As A Use Case. European Journal Of Remote Sensing, 51(1), 486-500. Https://Doi.Org/10.1080/22797254.2018.1451782

Subhan, S., \& Afu, L. O. A. (2017). Pengaruh Laju Sedimentasi Terhadap Rekrutmen Karang Di Teluk Kendari (The Effect Of Sedimentation Rate On Coral Recruitment In Kendari Bay). Jurnal Manusia Dan Lingkungan, 24(2), 73-80. Https://Doi.Org/10.22146/JML.23070

Sukiyah, E., Jassin, A. M. I., \& Fachrudin, K. A. (2020). The Impact Of ErosionSedimentations To Siltation Of Kendari Bay And Implications In Tourism Development Of Southeast Sulawesi, Indonesia. Journal Of Geological Sciences And Applied Geology, 4(2). Http://Jurnal.Unpad.Ac.Id/Gsag/Article/View/32226

Sukiyah, E., Sunardi, E., Sulaksana, N., \& Rendra, P. P. R. (2018). Tectonic Geomorphology Of Upper Cimanuk Drainage Basin, West Java, Indonesia. International Journal On Advanced Science, Engineering And Information Technology. Https://Doi.Org/10.18517/Ijaseit.8.3.5441

Sulaksana, N., Sukiyah, E., Sjafrudin, A., \& Haryanto, E. T. (2013). Karakteristik Geomorfologi Das Cimanuk Bagian Hulu Dan Implikasinya Terhadap Intensitas Erosi Serta Pendangkalan Waduk Jatigede. Bionatura-Jurnal Ilmu-Ilmu Hayati Dan Fisik.

Tian, Q., Wang, Q., \& Liu, Y. (2016). Geomorphic Change In Dingzi Bay, East China Since The 1950s: Impacts Of Human Activity And Fluvial Input. Frontiers Of Earth Science 2017 11:2, 11(2), 385-396. Https://Doi.Org/10.1007/S11707-016-0586-Z

Tampubolon, T., Yanti, J., \& Liu, C. Y. (2020). Spatial Correlation between Land Surface Properties and Cloud Characteristics in Indonesia. In Journal of Physics: Conference Series (Vol. 1428, No. 1, p. 012044). IOP Publishing.

Yasin, A. M., Sukiyah, E., Isnaniawardhani, V., \& Others. (2016). Fenomena Morfotektonik Pada Citra Srtm Di Wilayah Teluk Kendari. Bulletin of Scientific Contribution. 